Research Article

Open Access

Ineta Helmane

\title{
Emotions of Primary School Pupils in Mathematics Lessons
}

DOI 10.1515/sigtem-2016-0013

\begin{abstract}
The article describes and analyses theoretical and empirical materials about the pupils' emotions in the process of teaching/learning mathematics in a primary school. The aim of the article is to investigate the experienced emotions by pupils when learning mathematics in a primary school and highlight the factors arousing emotions in learning mathematics in primary school. The article analyses the data obtained in empirical research on the emotions experienced by pupils during mathematics lessons in primary school. In questionnaires and semi-structured interviews, pupils reveal what gave them positive emotions in mathematics lessons, as well as what made them experience negative emotions. Based on the analysis of empirical data, we highlighted the factors of learning mathematics in primary school that caused positive emotions; however, the failure to comply with these factors caused negative factors in pupils. As a result of the research, it is possible to select the factors facilitating positive emotions while teaching mathematics in primary school.
\end{abstract}

Keywords: mathematics, pupils, basic emotions, primary school.

\section{Introduction}

The great pace of life in the contemporary society demands emotionally powerful people, able to maintain a positive attitude towards life, overcome the fast increasing tension and stress, sustaining appropriate selfesteem and healthy self-confidence (Helmane, 2010). Children and adolescents have emotionally charged goals and cognitively appraise the degree to which a situation is hindering or promoting attainment of those goals, which leads to emotional reactions (OECD, 2010). Emotions mobilise each individual's mental and physical strength for the further activity to reach the goal, or prevent and hinder the individual's activities, participation in the diverse life - activity processes as well as in teaching/learning processes (Helmane, 2015). Emotions and cognition work together to guide learning processes (Hinton, Miyamoto, della Chiesa, 2008; Fischer, Bidell, 2006; OECD, 2010). Motivations and emotions are essential to education because together they ensure that pupils acquire new knowledge and skills in a meaningful way (OECD, 2010). Therefore, it is necessary to be aware of the factors that evoked positive emotions in pupils when learning mathematics at school and, consequently, encourage and mobilise pupils' mental and physical forces, which ensure a successful acquisition of mathematics skills.

\section{Aim of the Study}

The aim of the article is to highlight the experienced emotions by pupils when learning mathematics in primary school and highlight situations, stimuli and factors arousing emotions in learning mathematics in primary school.

*Corresponding author: Ineta Helmane: Riga Teacher Training and Educational Management Academy, Latvia,

E-mail: ineta.helmane@rpiva.lv 


\section{Materials and Methods}

\section{The essence of emotions}

The term 'emotion' is explained as reactions, both bodily reaction and the reaction system. For instance, emotion is a psycho-vegetative reaction of reflector linked with the expression of subjective attitude (in a way of emotional experience) towards the situation, its procedure (event) and promotion of reasonable behaviour in this situation (Ильин, 2001). Emotions are a type of body reaction including both response reaction and readiness to react to external conditions of agitation (Kingsly, Garry, 1970). Emotions are a system of early reactions which inform the body about the nearest future in its behaviour and the organisation of its behavioural forms (Дубровина, 1998).

Emotion is something that is experienced as a feeling which motivates, organises and promotes perception, thinking and action (Изард, 2000). Emotions have two major functions. First, they give high priority warning signals that interrupt ongoing activities and inform us that we are facing a highly valuable or threatening situation. The second important function is to prepare us to react swiftly in response. The increased level of arousal coincides with a secretion of hormones into the bloodstream, producing physical changes and providing the psychological and motivational energy to allow us to take action. We can observe in ourselves many of these changes, such as the heart beating faster, breathing becoming shallower or our hands feeling clammy (Frijda, 1986; OECD, 2010). Thus, emotions are a specific category of mental processes and states which are connected with instincts, needs, motives and reflects itself in indirect form of experience (joy, fear, etc) for the implementation of an individual's life in significant events and situations.

Basic emotions appear already in the first years of life through all cultures and with slight or without variations (Miezitis, 1992; Изард, 2000); they are based on the demonstration of a person's movements and expressions (Carlson, 1990). All basic emotions possess the following characteristic features: they attract a clear, strong feeling which a person is aware of; they develop as a result of evolution, i.e. biological processes; they have an organising and motivating affect on the person, serve for his adaptation (Изард, 2000) and manifest themselves in expressive and specific configuration of the movements of facial muscles, i.e. mimics (Изард, 2000; LeDoux, 1998). Basic emotions have their own brain substrates which are closely linked with brain structures ensuring the work of memory and other cognitive processes (Дружинина, Ушакова, 2002).

According to their polarity, basic emotions are divided into two big groups: positive basic emotions and negative basic emotions. Positive emotions are a signal of welfare, but negative emotions a signal of alarm and danger for the body (Ильин, 2001). The physiological base of such positive basic emotions as joy, interest, surprise (Изард, 2000; Carlson, 1990; Kagan, Havermann, 1980) is mainly excitation process. Positive emotions tone up the body's activities and activate the person, generate strength and energy as well as enhance the person's capability of mental work and increase energy (Рогов, 1999; Ильин, 2001; Изард, 1980; Carlson, 1990). Positive emotions primarily encoded information in long-term memory to signal that one is doing well, leading to a positive mood state and favourable judgements of one's own performance (Bower, 1991; OECD, 2010). However, negative basic emotions - anger, hatred, disgust, fear, shame, fault, sorrow (Изард, 2000; Carlson, 1990; Kagan, Havermann, 1980) - are based on retention process. Negative emotions usually depress, even paralyse a person as well as decrease a person's activity and also reduce energetic resources and the resources of body's information (Рогов, 1999; Банщиков, 1975; Carlson, 1990; Вилюнас, 1976; Ильин, 2001; Selighran, 1995). Therefore, emotions may have a positive or negative affect on a person's life processes, becoming a determining force of a person's action in crucial moments of life.

\section{Emotions in teaching/learning process}

In Latvia, already in the 1920s and 1930s, the correlation between teaching/learning process and emotions was stressed, emphasising that in teaching/learning process, it is advisable to point out everything that 
can generate positive emotions, because what brings joy attracts everybody (Hergets, 1923; Students, 1935; Svenne, 1930). A monotonous, boring learning process and failures cause negative emotions (Дубровина, 1998; Selighran, 1995). If we do something with pleasure, we will try to do the same in future, however, if we do something with negative emotions, it means that we will try to stop doing it in all possible ways in future (Виготский, 1999). In such a way, one of the functions of emotions is exposed. Emotions take part in teaching/learning process and also the process of accumulating experience, when the positive emotions evoked by the interaction between the human body and environment promote the consolidation of fruitful methods and activities but the negative ones make escape from harmful factors (Лук, 1982; Skemp, 1989). Some of these emotions, such as anger and relief, are short-lived and have little significance for future learning. Other emotions, such as shame and hopelessness, have enduring relevance to classroom learning because they are tagged to learning situations and will be activated when a pupil is confronted with similar tasks in the future (OECD, 2010).

The teaching/learning process based on positive emotions proceeds more successfully (Ильин, 2001). Within positive emotions, a more profound approach to the acquisition of various skills and knowledge develops, which facilitates openness to new things, creativity and energy to be productive (Olson, Torrance, 1996; Дружинина, Ушакова, 2002; Gorman, 2001). The pupil's positive emotions towards certain activities arouse a desire and need to perform the necessary activities with great fervor and enthusiasm (Якобсон, 1966). The encountered positive emotions become a strong motivating, suggestive factor for future actions (LeDoux, 1998). Positive emotions energise pupils because they direct attention towards relevant cues in the task and the learning environment to create an optimal internal environment for learning, self-regulation and achievements (OECD, 2010). If successful, emotions positively motivate and reinforce several extremely successful activities, guesses and ideas, which came up during the completion of tasks. However, the negative emotions reduce the effectiveness of learning, the ability to acquire various types of knowledge, skills as well as inhibit creativity (Olson, Torrance, 1996; Абрамова, 2003; Pound, Trisha, 2011). Negative emotions are prime-encoded information in long-term memory and signal to the pupils that something is wrong (Bower, 1991; OECD, 2010). This triggers a negative mood and unfavourable judgements of the task and one's performance of it. Negative emotions may also indicate that the learner's psychological needs for competence, autonomy and social relatedness are frustrated (OECD, 2010).

Learning mathematics is connected with the pupil's individual experience in mathematics and applying it in everyday life, the perspective of his individual learning where emotional factors are as significant and important as cognitive factors in psychological learning process (Tosse, Falkencrone, Puurula, Bergstedt, 1998). The value of emotions in learning process is related to emotions; nobody can develop mathematics or intellectual values without emotions, especially in mathematics. The positive learning experience can help to change negative thoughts and feelings and raise pupils' motivation in learning process (Paris, Ayers, 1994).

\section{Research of pupils' emotions in mathematics lessons}

The research of emotions experienced by pupils in mathematics lessons in primary school was carried out in Grade 3 in five Riga secondary schools. The research was done within the academic year over the period from 2014 to 2015, in a total of 124 pupils (age 8-9). In research, the pupils self-evaluate positive and negative emotions while learning mathematics in primary school were explored.

The data were obtained applying such empiric research methods as questionnaires and semi-structured interviews (Helmane, 2010; Helmane, 2015). The aim of questionnaires was to select the self-evaluated emotions by pupils in mathematics lessons in primary school and the factors, situations, stimuli evoking emotions in learning mathematics in primary school. The aim of semi-structured interviews was to specify the pupils self-evaluate positive and negative emotions when learning mathematics in primary school and the factors, situations, stimuli evoking emotions in mathematics lessons in primary school.

The pupils were asked to fill in a questionnaire of the self-evaluation about experienced emotions while learning mathematics. The pupils of Grade 3 involved in the research marked individually on Likert-type 
scale self-evaluation of positive and negative emotions experienced while learning mathematics in primary school. When marking self-evaluation of emotions, the pupils took into consideration Likert-type scale where 1 point corresponds to the answer - negative emotions, no positive emotions, 3 points correspond to the answer - both positive and negative emotions, but 5 points mean - positive emotions, no negative emotions. During the further survey, the pupils individually reflected and pointed out at least three factors, stimuli, situations which evoked positive emotions at school as well as pointed out at least three factors, stimuli, situations when they felt negative emotions. The data obtained from questionnaires were specified in a semi-structured interview where the pupils supplemented the answers to the questions regarding the factors, stimulus, and situations evoking emotions. The peculiarity of this interview was that the questions previously were not formulated precisely, and also their succession was not strictly determined; however, during the interview, it was clarified to what extent, on what conditions, in which situations the pupils experienced positive or negative emotions while learning mathematics in primary school as well as specified the factors, situations, stimulus evoking these emotions. Each interview was about 15 minutes long. It was recorded, transcribed and coded.

\section{Results}

The data obtained according to Likert-type scale as a result of questionnaires by 124 pupils testify that during school time, pupils experienced positive and negative emotions at almost an identical intensity. Also, we can observe the cases of dual polarity where pupils experienced extremely negative emotions and extremely positive emotions while learning mathematics. It is characteristic that positive emotions experienced by pupils dominate while learning mathematics (see Figure 1). There is no significant difference between the data obtained in the previous studies (Helmane, 2010; Helmane, 2015).
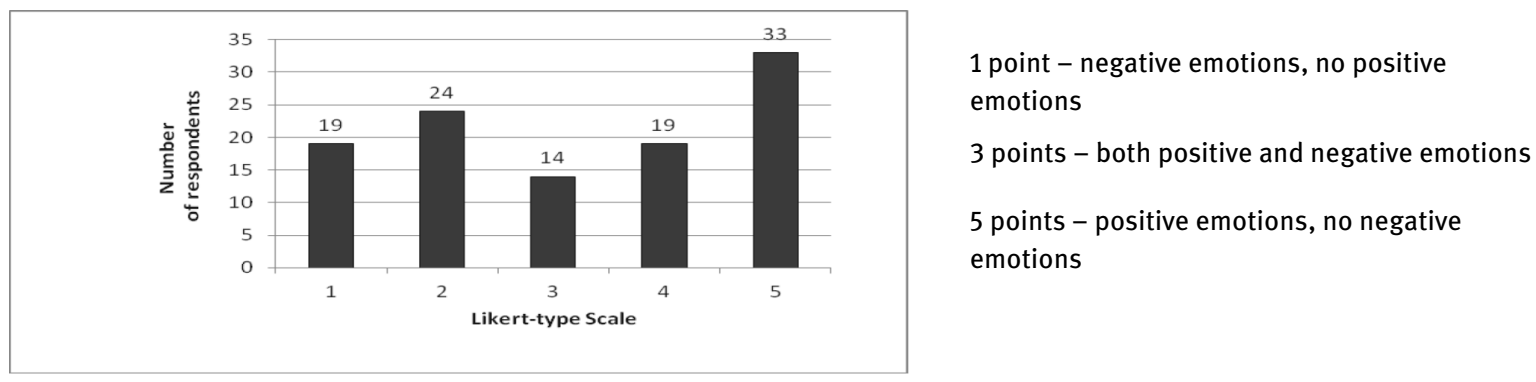

Figure 1. Experienced emotions of pupils in mathematics

The data obtained in the questionnaires and semi-structured interviews were analysed according to previously set out questions for the research:

1. What pupils acquire in mathematics in the primary school? Answers to this question corresponds with interrelationship of the pupil's emotions and skills, knowledge as components of the mathematics content.

2. How pupils acquire skills and knowledge mathematics content in primary school? Answers to research question highlight interrelationship of the pupil's emotions and varied organisation of educational work, different strategies in the mathematics teaching/learning.

3. Wherefore pupils acquire skills and knowledge in mathematics? Answers show interrelationship of the pupil's emotions and different aspects of assessment in mathematics in primary school.

A dominant situation, factors and stimulus generating positive emotions is a varied organisation of educational work where the students emphasise the tasks about life situations, manipulations and games. Whereas dominant situation, factors and stimulus generating negative emotions are mathematics content when pupils mastering multiplication, fractions as well as world problems (see Table 1). 
Table 1. Pupils' positive and negative emotions in mathematics 3rd Grade

\begin{tabular}{|c|c|c|c|}
\hline \multirow{2}{*}{ Question and Criterion } & \multirow{2}{*}{ Indicator / Conditions, situations } & \multicolumn{2}{|c|}{ Pupils' emotions (\%) } \\
\hline & & Negative emotions & Positive emotions \\
\hline \multirow{4}{*}{$\begin{array}{l}\text { What? } \\
\text { Mathematics content }\end{array}$} & Text tasks / word problems & 79 & 17 \\
\hline & Addition and subtraction & 13 & 71 \\
\hline & Multiplication & 74 & 22 \\
\hline & Fractions & 61 & 34 \\
\hline \multirow{4}{*}{$\begin{array}{l}\text { How? } \\
\text { Strategies and organisation of } \\
\text { teaching/learning }\end{array}$} & Manipulations & 5 & 89 \\
\hline & Tasks about life-situations & 18 & 76 \\
\hline & Monotony, hurry, pupils' passivity & 68 & 2 \\
\hline & Games & 4 & 96 \\
\hline \multirow{4}{*}{$\begin{array}{l}\text { Wherefore? } \\
\text { Assessment }\end{array}$} & Achievements & 9 & 87 \\
\hline & Failures & 79 & 23 \\
\hline & Recognition for achievements & 2 & 69 \\
\hline & Tests, competitions & 67 & 35 \\
\hline
\end{tabular}

When analysing the data about interrelationship between the pupils' emotions and skills, it is necessary to specify the content of mathematics and its composition in primary school. The content of mathematics to be acquired is determined by Basic Education Standard, 2006 where it is indicated which skills and knowledge pupils have to acquire when finishing Grades 3, 6 and 9. It is characteristic that already since the 1920s and 1930, mathematics content has been organised in concentres (circles). When organising mathematics content concentrically, it is necessary to take into consideration that in concentric circles or gradual breakdown, mathematics content has to pass all the grades, where in every next grade, mathematics content expands and comprises the content of all previous grades. For instance, at the beginning of mathematics studies, its content comprises two arithmetic operations (addition and subtraction) within the first 10; later the range of operations expand to a hundred, after that to a thousand etc., thus, implementing the concentric breakdown of mathematics content (Pētersons, 1931). When characterising mathematics content, pupils in most of the cases mention the acquisition of problem solving and multiplication within the table as a factor which evoked negative emotions while learning mathematics (see Table 1). In semi-structured interviews, pupils clarify the experienced negative emotions as incomprehension about the necessary activities for doing the task, an insufficient skill to read a word problem. Most of the pupils emphasise that negative emotions while solving word problems were experienced also because there are too many word problems in textbooks and they are stylistically the same. Also, the word problems did not arouse their interest and did not have connection with real life and the surrounding processes.

When mastering multiplication within the table, pupils named the main reason for having negative emotions, i.e. learning multiplication table by heart without the comprehension about relationships in the multiplication table. In the semi-structured interview, the pupils pointed out that they experience negative emotions because multiplication has to be done very quickly, and they must memorise it like a poem. The reason for these negative emotions can be found in the approaches to acquisition of multiplication, which have dominated in Latvian schools since the 1970s. According to the pupils' answers in the semi-structured interview, swotting, drill and task sameness still dominate in the acquisition of multiplication.

Experienced negative emotions are in the acquisition of fractions, pupils emphasised that the tasks with fractions are difficult, they are only partly connected with manipulation, practical examples. The pupils noted that they are afraid to do the tasks with fractions; they also cannot solve the problems where they have to calculate part of the figure. The relationship between fractions and negative emotions obtained in the pupils' questionnaires and semi-structured interview might be explained by the methodological approach used in teaching/learning about fractions. In most study aids issued in Latvia, a fraction is acqui- 
red by dividing only one whole in parts (Mencis, 2000; Valtasa, Lude, 2005).

Pupils experienced positive emotions most often while mastering addition and subtraction skills at school. Pupils point out that they willingly did arithmetic operations; it was easy and understandable, for instance see Figure 2. The pupil commented his drawing in the following way: It is so cool that there are a lot of figures, I can calculate with them. It's fun!

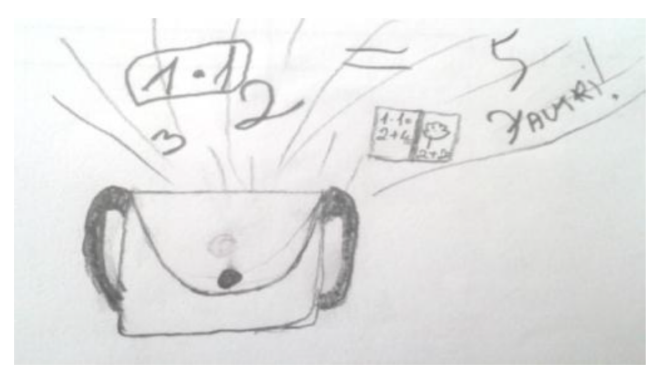

Figure 2. A drawing by a $3^{\text {rd }}$ grade pupil

The majority of pupils confirmed in the semi-structured interview that in mathematics lessons, it was interesting to do manipulations with small countable material, to model various life situations, playing games.

Very often in questionnaires, pupils mentioned their personal achievements and success in mathematics lessons as a prerequisite initiating positive emotions when each success allowed to experience positive emotions (see Table 1). Also, the recognition of the achieved has often evoked positive emotions whereas failures in most of the cases caused negative emotions in pupils. The pupil's mistakes were not perceived as an opportunity to develop, correct mistakes and master the skill. For instance, the pupil perceives mistakes as a resource which helps him to learn. He commented: I don't have to worry about mistakes. I can learn from them. I like mathematics and I do not hate it (see Figure 3).

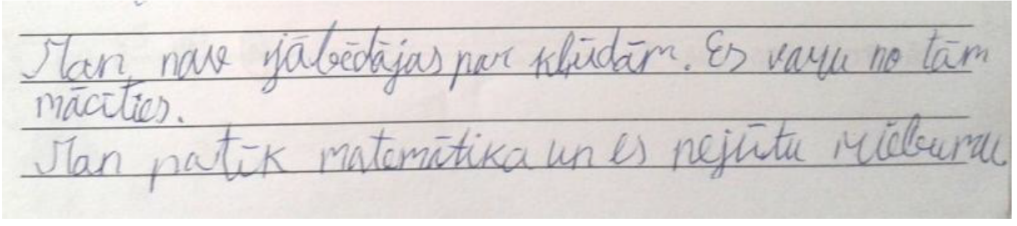

Figure 3. The pupil's commentary on mistakes

Negative emotions in pupils were initiated by monotonous, repetitive mathematics lessons where pupils were passive performers of the teacher's instructions. Pupils point out that they feel bored in the mathematics lessons where there are the same activities: individual work, frontal work, drill.

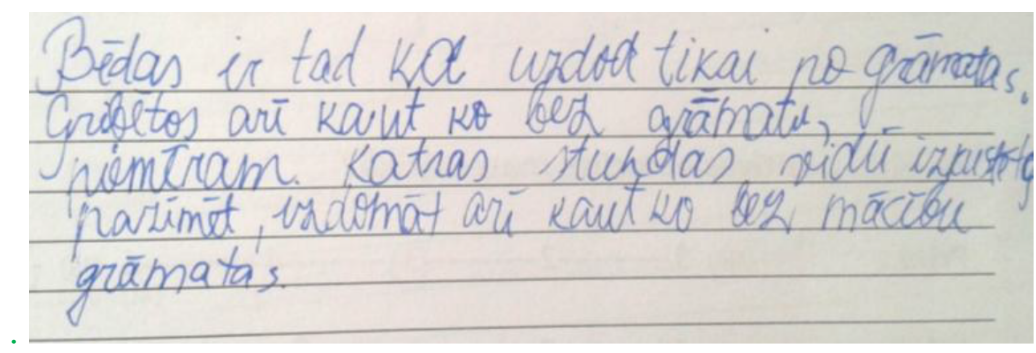

Figure 4. The pupils's commentary on the textbook

In most cases, the textbook is used as a resource for tasks and their solution. The pupil noted that in mathematics lessons, the work with the textbook dominates. However, the pupil's needs and interests are 
wider than the tasks in the textbook which cannot satisfy him: It is sad when the teacher gives tasks only from the book. I would like to have something apart from the book, for example, to draw in the middle of the lesson or think about something that is not in the textbook (see Figure 4).

Consequently, the quality of educational process is affected by the emotions experienced by the pupil during the teaching/learning process at school. These emotions initiate mental and physical strength or hinder them. The positive emotions experienced while learning mathematics facilitate the acquisition of mathematical skills and knowledge as well as lead to the desire to develop the acquired skills and apply them in various life situations. In its turn, the negative emotions experienced in mathematics cause a dislike to mathematics in pupils, they are unwilling to improve and apply the obtained skills in further activities.

\section{Conclusions}

Emotions mobilise each individual's psychic and physical strength for the further activity to reach the goal, or prevent and hinder the individual's activities, participation in the diverse life-activity processes. It is necessary to be aware of the factors which evoked positive emotions in pupils when learning mathematics in school and, consequently, encourage and mobilise pupils' mental and physical forces, which ensure a successful acquisition of mathematics skills.

The factors, situations and stimuli facilitating positive emotions while teaching/learning mathematics in primary school: curriculum, teaching/learning strategies and assessment. Curriculum should be easy for a pupil to understand and perceive, which is encouraging, in good arrangement, intensity and appropriate difficulty level. Mathematics teaching/learning should include efficient techniques of work and visual aids are used in the acquisition of skills; also the pupils' activities are practical and independent; diverse forms of work and strategies, especially the game are used in the acquisition of skills, which encourage a pupil's active participation and mobilisation of potential in order to achieve the desired objective. Evaluation of a pupil's progress and achievements by the teacher, peers and also self-esteem is important part in mathematics teaching/learning.

\section{References}

Brower, G.H. (1991). Mood Congruity of Social Judgment, in J.Forgas (ed.), Emotion and Social Judgment, Pergamon, Oxford, UK

Carlson N.R. (1990). Psychology. USA: Allyn and Bacon.

Fisher, K.W., Bidell, T.R. (2006). Dynamic Development of Action, Thought and Emotion in Damon W., Lerner R.M. (eds.), Theoretical Models of Human Development, Handbook of Child Psychology, Wiley, New York, Vol. 1, pp.331-339.

Frijda, N.H. (1986). The Emotions. Cambridge University Press, Cambridge, UK.

Gorman J.C. (2001). Emotional Disorders \& Learning Disabilities in the Elementary Classroom. California: Corwin Press. Helmane, I. (2010) Mathematical skills acquisition and pupils emotions in the primary school. Teacher of the 21st Century: Quality education for quality teaching. ATEE Spring University. 476.-485.p.

Helmane, I. (2015). Basic emotions of primary school pupils in mathematics lessons. Proceedings of the Ninth Congress of the European Society for Research in Mathematics Education, CERME 9, Prague, Czech Republic.

Hergets A. (1923). Pedagoǵika I. Rīga: Izglīīības Ministrijas izdevums, (in Latvian).

Hinton, C., Miyamoto, K., Chiesa, B.della (2008). Brain research, Learning and Emotions: Implications for Education Research, Policy and Practice, European Journal of Education, Vol.43, No.1, pp.87-103.

Kagan G., Havermann E. (1980). Psychology. New Jork: Harcourt Brace Jovanovich.

Kingsly H.L., Garry R. (1957). The Nature and Conditions of Learning. New Jersey: Englewood Cliffs Prentice- Hall.

LeDoux J. (1998). The Emotional Brain. London: Weidenfeld \& Nicolson.

Mencis, J. (sen.), Krastiṇa, E., Oliṇa, D., Mencis, J. (jun.) (2000). Matemātika 4.klasei (Mathematics 4st grade). Rīga: Zvaigzne ABC (In Latvian)

Miezitis S. (1992). Creating Alternatives to Depression in Our Schools. Toronto: Hogrefe \& Huber Publ..

OECD (2010).The Nature of Learning: Using Research to inspire practice. OECD publications.

Olson D.R., Torrance N. (ed.) (1996). The handbook of Education and Human Development. USA: Blackwell Publishers Ltd..

Paris S.G., Ayers L.R. (1994). Becoming Reflective Students and Teachers with Portfolios and Authentic Assessment. Washington: Americas Psychologists Association. 
Pētersons, Ed. (1931). Vispārīgā didaktika. Rīga, A.Gulbis (in Latvian).

Pound L., Trisha L. (2011). Teaching Mathematics Creatively. London: Routledge.

Selighran M.E.P. (1995). The Optimistic Child. Boston: Houghton.

Skemp R.R. (1989). Mathematics in the primary school. London: Routledge.

Students J.A. (1935). Bērna, pusaudža un jaunieša psichologiija. Rīga: Autora izdevumā, (in Latvian).

Svenne O. (1930). Modernie audzināšanas talanti. Rīga: Auseklis, (in Latvian).

Tosse S., Falkencrone P., Puurula A., Bergstedt B. (1998). Corporate and non formal learning. Trondheim: Tapir Forlag. Valsts Pamatizglītības standarts. (2006). Mācību priekšmetu programma pamatizglītībā. Matemātika [National Basic

Education Standard. Mathematics]. Retrieved 12.10.2016. from http://visc.gov.lv/vispizglitiba/saturs/dokumenti/ programmas/pamskolai/mat1_9.html (in Latvian).

Valtasa, I., Lude, I. (2005). Matemātika 4.klasei (Mathematics 4st grade). Rīga: Pētergailis (In Latvian)

Абрамова Г.С. (2003). Возрастная психология. Москва: Академический Тракт, (in Russian).

Банщиков В.М., Завялов В.Ю., Короленко Ц.П. (1975). Эмочии и воображения. Москва: ВНОНП, (in Russian).

Вилюнас В.К. (1976). Психология эмочиональных явлений. Москва: Московский университет, (in Russian).

Виготский Л.С. (1999). Педагогическая психология. Москва: Педагогика Пресс, (in Russian).

Дубровина И.В.,Прихожан А.М. (1998). Возрастная и педагогическая психология. Москва: Академия, (in Russian). Изард Е.К. (2000). Психология эмочий. СанктПитербург: Питер, (in Russian).

Изард Е.К. (1980). Эмочии человека. Москва: Московский университет, (in Russian).

Ильин Е.П. (2001). Эмочии и чувства. СанктПитербург: Питер, (in Russian).

Дружинина В.Н., Ушакова Д.В. (2002). Когнитивная психология. Москва: ПерСЕ, (in Russian).

Лук А.Н. (1982). Эмочии и личность. Москва: Знание, (in Russian).

Рогов Е.И. (1999). Эмочии и воля. Москва: Владос, (in Russian).

Якобсон П.М. (1966). Эмоциональная жизнь школьника. Москва: Просвещение, (in Russian). 